Research Article

\title{
Research on the Wing-Type Antiscour Device of Pier Based on Scour Test and Numerical Simulation
}

\author{
Yan Wang $\mathbb{D},{ }^{1}$ Xiaoli Shen, ${ }^{1}$ Jinchao Chen, ${ }^{1}$ Zhejiang Chen, ${ }^{2}$ and Jing Liu ${ }^{3}$ \\ ${ }^{1}$ School of Civil Engineering and Architecture, Zhejiang Sci-Tech University, Hangzhou 310018, China \\ ${ }^{2}$ Jinhua City Transportation Investment Group Co., Ltd., Jinhua 321015, China \\ ${ }^{3}$ Dongyang Highway and Transportation Management Center, Dongyang 322100, China \\ Correspondence should be addressed to Yan Wang; an_wangyan@126.com
}

Received 28 July 2021; Revised 18 October 2021; Accepted 29 November 2021; Published 15 December 2021

Academic Editor: Zhoujing Ye

Copyright (C) 2021 Yan Wang et al. This is an open access article distributed under the Creative Commons Attribution License, which permits unrestricted use, distribution, and reproduction in any medium, provided the original work is properly cited.

In order to reduce the local scour before the antiscour device of piers, this paper proposed an improvement on a "V-type" device. That was to say, wing plates were set on the surface of the "V-type" device to enhance the diversion and reduce the local scour. To explore the protection effect of the modified device, the inclination angles of the wing plates were set to three angles, and the scour characteristics around the device were studied through the flume scour test and numerical simulation test. The results showed that the wing plates can reduce the impact force of the diving flow which was at the front end of the protective device. Besides, they could also disturb the flow around both sides of the device and weaken its sediment carrying capacity. Thus, the local scour around the device was effectively reduced. Especially, when the wing plates were $30^{\circ}$, the performance of reducing the local scour was the best.

\section{Introduction}

The local scour of bridge piers is one of the main reasons for water damage of bridges [1-7]. Over the years, many scholars have investigated and counted a series of bridge damage accidents caused by local scour. Kan et al. [8] sorted out the data of 155 bridge water damage accidents, of which $75.4 \%$ were caused by local scour. Wardhana and Hadipriono [9] studied 500 bridge damage accidents, of which $52.9 \%$ were caused by local scour. Thus, it is urgent to take some protective measures to reduce it.

According to the protection mechanism of local scour $[10,11]$, the protection measures for local scour of piers can be divided into two categories: active protection and passive protection. Active protection is carried out by changing the flow structure around the pier; passive protection is carried out by improving the antiscour capacity of the riverbed through the protective devices. The research shows that active protection is more economical and effective than passive protection and has better application prospects [12]. In view of the protective mechanism, previous scholars have carried out a lot of research studies. Wei and Dargahi[13, 14] proposed the method of setting a retainer at a certain height of the pier to weaken the kinetic energy of the water flow in front of the pier; Chiew et al. $[15,16]$ proposed the method of slotting the pier body to weaken the submerged flow in front of the pier; Lan and Zhou et al. $[17,18]$ proposed the method of setting a apron at the lower part of the pier to reduce the effect of eddy current around the pier. Garg et al. [5] proposed the method of installing collar plates around the pier to reduce horseshoe vortex around the pier. In short, these protection methods effectively reduce the local scour around the pier, but most previous studies consider setting the protective structure on the pier, which will be inconvenient in the early construction or later maintenance.

Based on this, our previous study [19] proposed a "Vtype" protective device installed in front of the pier, which had the characteristics of combining active protection and passive protection. It could not only actively block the water and played a good role in sheltering the bridge pier but also could disperse the water flow and at the same time was very convenient for construction. Previous studies have shown 
that [19] when the protective devices were $3.5 \mathrm{~d}$ away from the pier center ( $\mathrm{d}$ denotes the pier diameter), the angle of the protective device was $60^{\circ}$, the height of the protective device was $3 \mathrm{~h} / 4$ (h denotes the water depth), and the width of wing plates was $9 \mathrm{~d} / 40$; the protection effect was the best.

However, this new type of antiscour device caused local scour around the device. Because of the water resistance of the device, the water flow could not pass quickly. As a result, an upward flow was formed at the front end and both sides of the device. At the same time, a diving flow was generated in the lower area of the upstream surface of the device. Such circulation caused local scour around the device, thus reducing its service life. Therefore, this paper proposed some improvements based on previous research studies. We added two rows of wing plates on the surface of the device to reduce the scour around the device and make it play a better role in protecting the pier. The two rows of wing plates were symmetrically distributed along the middle vertical line. They disturbed the upward flow at the front end and both sides of the device and separated the diving flow on the upstream surface, so as to weaken the eddy current system.

\section{Structure of Protective Device}

As shown in Figure 1, $0.03 \mathrm{~cm}$ thick sheet iron with the size of $30 \mathrm{~cm} \times 8 \mathrm{~cm}$ was folded into the protective device along the short side. The protective device had an angle of $60^{\circ}$, a height of $3 \mathrm{~h} / 4$ (h denotes the water depth), and a width of wing plates is $9 \mathrm{~d} / 40$ ( $\mathrm{d}$ denotes the pier diameter). The modified protective devices had two rows of wing plates on the upstream surface, and the inclination angles of the wing plates were designed as $0^{\circ}, 15^{\circ}$, and $30^{\circ}$.

\section{Test Device and Plan}

3.1. Test Device. In the test, a $3 \mathrm{~m}$ long, $0.8 \mathrm{~m}$ wide, and $0.5 \mathrm{~m}$ high flume with a water depth of $10 \mathrm{~cm}$ was used, and an independent water supply and return system was equipped. The inlet section was $0.2 \mathrm{~m}$ long, the inlet transition section was $0.7 \mathrm{~m}$ long, the test section was $1.2 \mathrm{~m}$ long, the outlet transition section was $0.5 \mathrm{~m}$ long, and the backwater area was $0.4 \mathrm{~m}$ long. The current meter was arranged in front of the pier to monitor the flow rate; the test flow rate was $0.20 \mathrm{~m} / \mathrm{s}$. The model pier was PVC pipe with a diameter of $4 \mathrm{~cm}$ and height of $40 \mathrm{~cm}$. The protective device was placed $3.5 \mathrm{~d}$ away from the pier center. Natural river sand with an average grain size of $0.8 \mathrm{~mm}$ was used in the simulated riverbed, with a thickness of $15 \mathrm{~cm}$. The saturated density and dry density of the sand were $2.298 \mathrm{~g} / \mathrm{cm}^{3}$ and $1.768 \mathrm{~g} /$ $\mathrm{cm}^{3}$, respectively. The layout of the test system is shown in Figures 2(a) and 2(b).

Before the start of each test condition, the sediment of the whole riverbed was leveled and soaked in water for more than 1 hour. After the sediment settlement was stable, the feed water flow gradually increased to the experimental design flow, and the water volume reached the design water level. Then, the test was officially started until the scouring reaches a stable balance, and each scouring time was more than 4.5 hours.
3.2. Test Plan. There were two kinds of tests in this paper. The first was to compare the protective device with or without wing plates through indoor flume test and numerical simulation experiment, to verify the effectiveness of wing plates. The second was to change the inclination angles of the wing plates, to study the influence of the inclination angles of the wing plates on the local scour around the protective device. The inclination angles of the wing plates were set to three angles, $0^{\circ}, 15^{\circ}$, and $30^{\circ}$. The design was carried out according to the principle of the orthogonal test, with 4 groups of working conditions, as shown in Table 1. In all tests, three measuring points were arranged at the front end, left end, and right end to measure the scour depth around the device, as shown in Figure 2(c).

3.3. Analysis Model. As shown in Figure 3, to verify the accuracy of physical test results, a numerical analysis model was established by using CFD (computational fluid dynamics) fluent. The $3 \mathrm{D}$ model did not need to regulate the water flow, so only the test section was simulated. The total length of the three-dimensional model was $1.2 \mathrm{~m}$, and the width was $0.8 \mathrm{~m}$. The pier was placed in the center of the model, and the center of the pier was $0.6 \mathrm{~m}$ from the front block of the test section and $0.4 \mathrm{~m}$ from both walls of the water tank. The distance between the protective device and the pier center was $3.5 \mathrm{~d}$. The parameters of protective device and pier were consistent with those of the indoor test. The riverbed surface was horizontal. The first layer of the model was water layer, and the second layer was sand layer.

After trial calculation, it was finally determined that the model adopted unstructured grid, the average number of grids was about $5 \times 10^{5}$, and the average quality of model grid was more than 0.83 , which could meet the calculation requirements of fluent. In this model, the inlet boundary was set at the upstream $0.6 \mathrm{~m}$ away from the pier center. The inlet was the water inlet and was set as the velocity boundary condition. The outlet boundary was set at the downstream of the flume $0.6 \mathrm{~m}$ away from the pier center. The water outlet was connected with the atmosphere, which was set as free outflow, and the boundary condition was set as free outflow boundary. Other walls, piers, and protective devices of the flume were set as wall conditions or symmetrical boundary conditions without sliding boundary conditions. The gravity acceleration direction simulated by the model was in the $z$-axis direction, and the sediment particle size referred to the physical test. The sediment was composed of silicon by default, and the parameters such as drag coefficient and coiling coefficient adopted the default value. In the simulation, the velocity time was set as $40 \mathrm{~s}$.

\section{Result Analysis}

4.1. Effectiveness Analysis of Wing Plates. Scour depth is an important index to evaluate local scour degree [20-23]. To verify the effectiveness of the wing plates, the scour depths of the protective device with or without the wing plates were compared, and the inclination angles of the wing plates were 

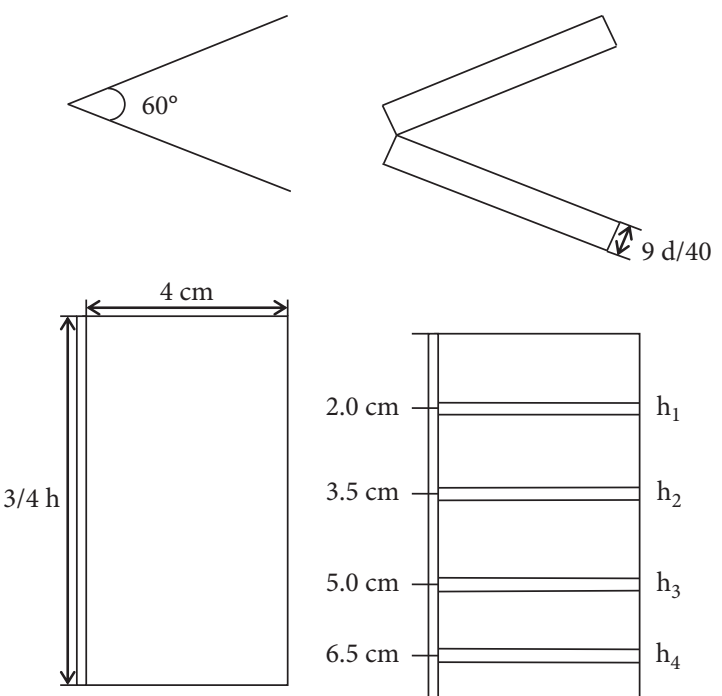

(a)

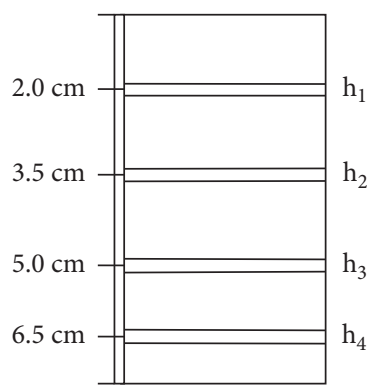

(b)
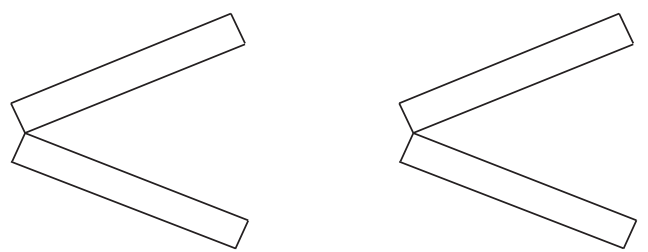

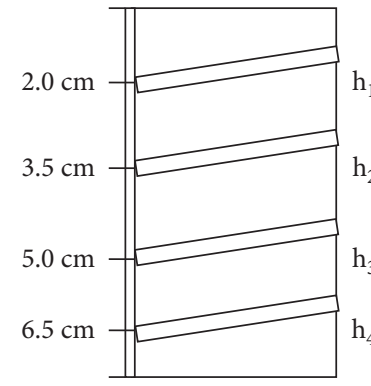

(c)

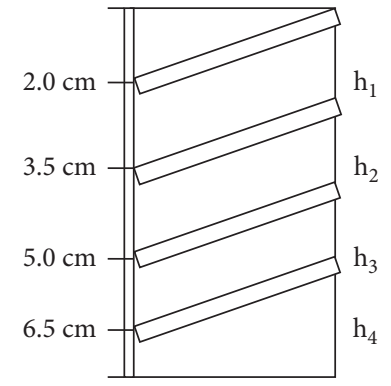

(d)

Figure 1: Protective device model: (a) wingless plate; (b) $0^{\circ}$ dip angle; (c) $15^{\circ}$ dip angle; (d) $30^{\circ}$ dip angle.
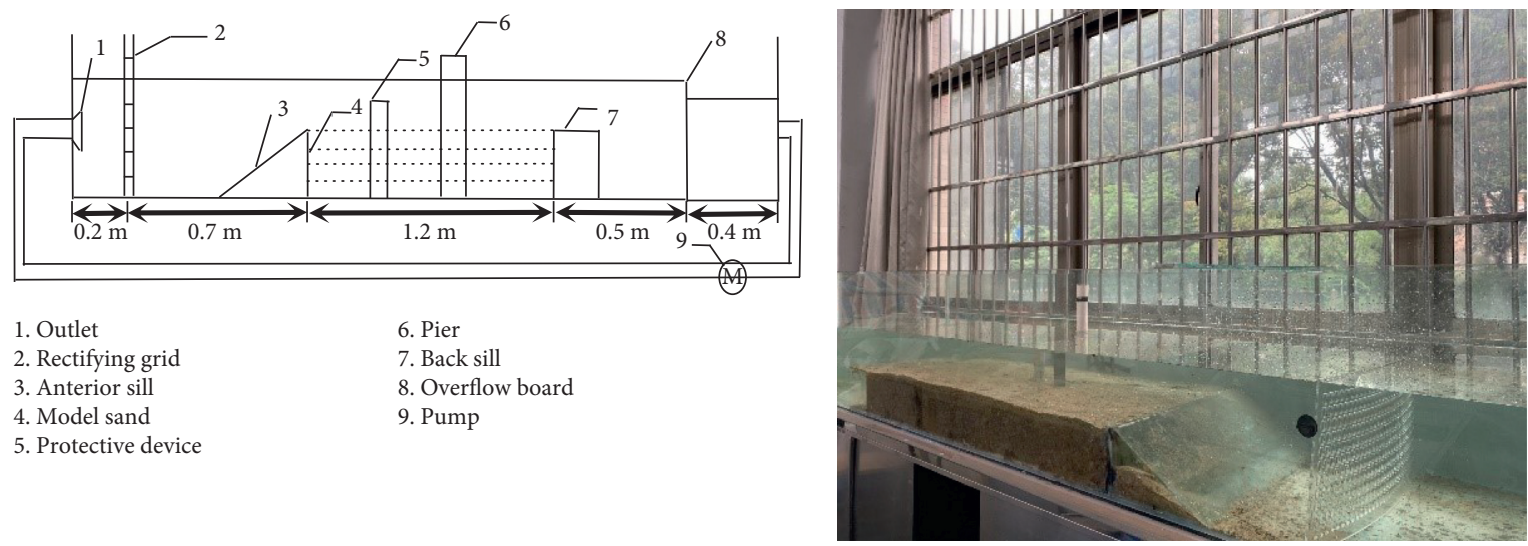

(a)

(b)

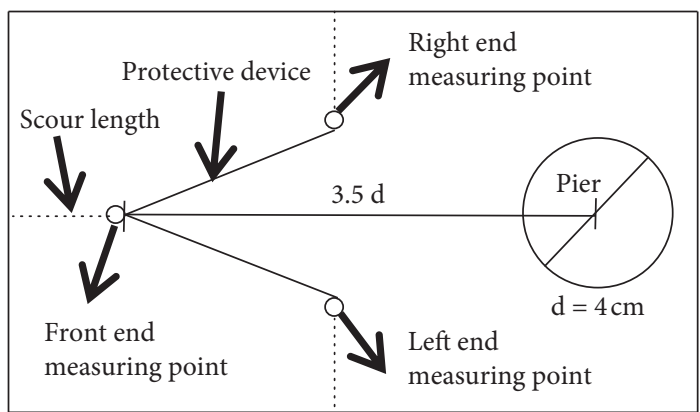

(c)

Figure 2: Test layout: (a) flume model; (b) site layout; (c) layout of scour depth measuring points.

TABLE 1: Test conditions.

\begin{tabular}{lcc}
\hline Test conditions & Type & $\begin{array}{c}\text { Test variables } \\
\text { Wing inclination }\left(^{\circ}\right)\end{array}$ \\
\hline 1 & Wingless plate & - \\
2 & & 0 \\
3 & With wing plate & 15 \\
4 & & 30 \\
\hline
\end{tabular}

kept constant at $0^{\circ}$. To ensure the accuracy of the test data, the scour depth was measured after the scour was stable. Figure 4 shows the scour pit characteristics of the protection device. Figure 5 shows the simulation scour characteristics of the protection device. From the figure, it could be seen that the scour phenomenon of the whole riverbed plane was more obvious at the position of the protective device and the 




(a)

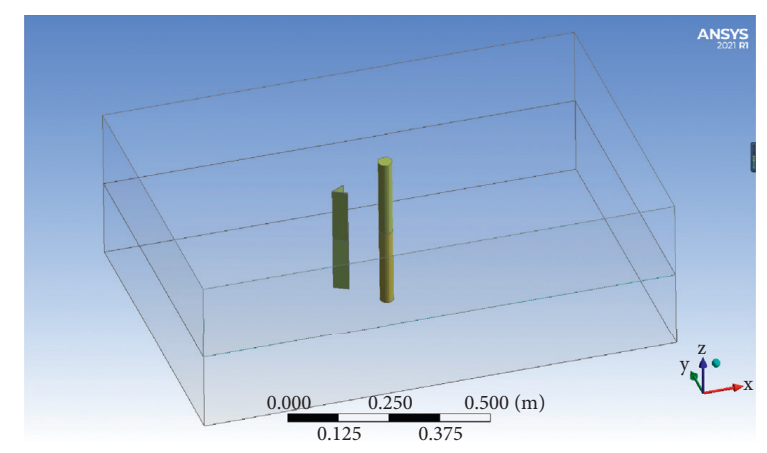

(b)

Figure 3: Numerical analysis model: (a) model side view; (b) three-dimensional model.

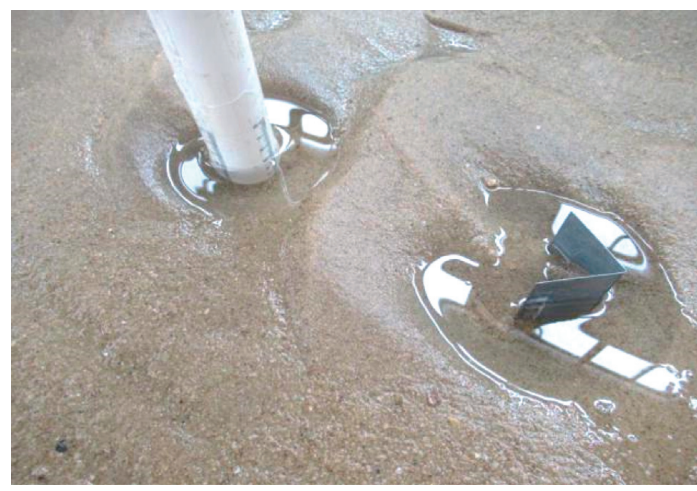

(a)

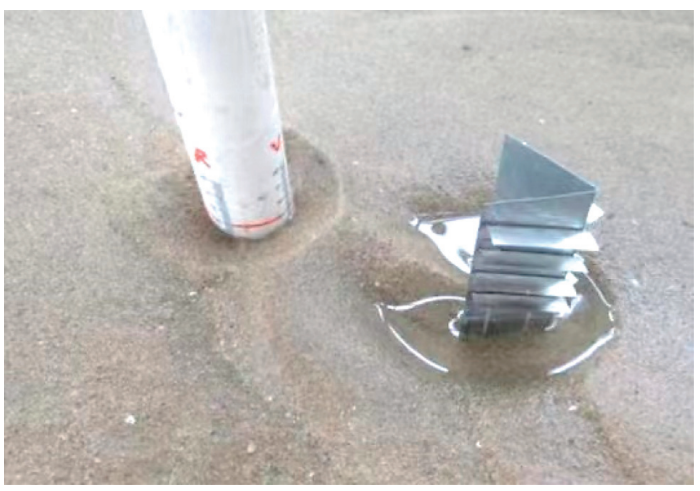

(b)

FIgURE 4: Characteristic map of scour pit: (a) wingless plate; (b) with wing plate.

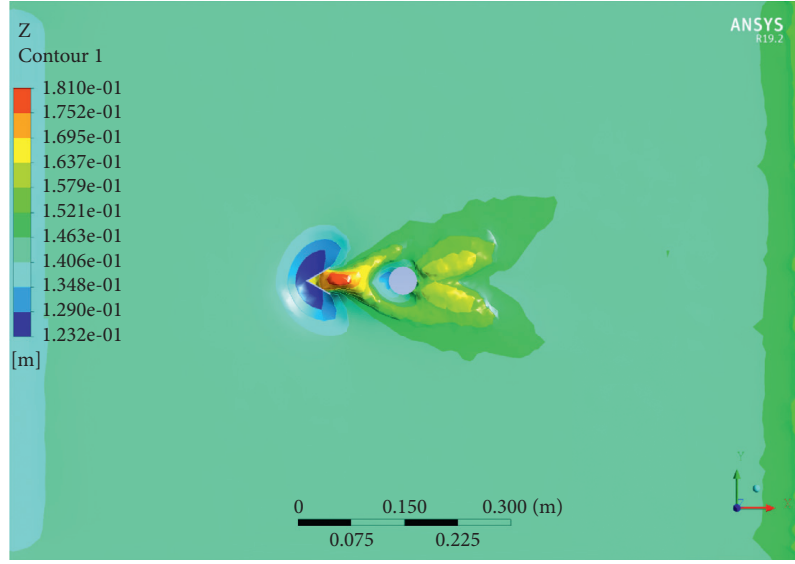

(a)



(b)

Figure 5: Cloud chart of scour depth: (a) wingless plate; (b) with wing plate.

pier. The upstream surface of the protective device was in the scour area, and the surrounding sediment was eroded. And the back surface of the device belonged to the sediment accumulation area. The front end of the device was the starting point of scouring, and the left and right ends were the end points of scouring. Therefore, measuring points were arranged at these three positions to measure the scour depth of the protective device. 




(a)

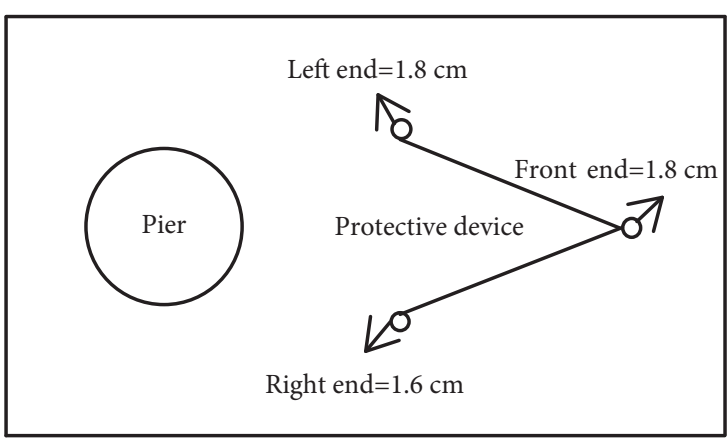

(b)

Figure 6: Scour depth detail: (a) wingless plate; (b) with wing plate.

TABLE 2: The results of scour depth.

\begin{tabular}{lccccccc}
\hline \multirow{2}{*}{ Test conditions } & \multirow{2}{*}{ Type } & \multicolumn{3}{c}{ Simulated values $(\mathrm{cm})$} & \multicolumn{3}{c}{ Test value (cm) } \\
& & Front end & Left end & Right end & Front end & Left end & Right end \\
\hline 1 & Wingless plate & 2.6 & 2.4 & 2.4 & 1.9 & 1.9 & 1.7 \\
2 & With wing plate & 2.5 & 2.0 & 2.0 & 1.8 & 1.8 \\
\hline
\end{tabular}

To analyze the effectiveness of the wing plate more concretely, this paper measured the scour depth of each measuring point of the protection device before and after the improvement and sorted out the data into Figure 6 and Table 2. This test mainly used a square to measure the scour depth. During the test, the scour depth of each measuring point was measured repeatedly for five times, and finally the average value was taken, and the error was within 5\%. According to Figure 6, it could be found that after the wing plates were added, the test values at the front end, left end, and right end were all reduced by $0.1 \mathrm{~cm}$. According to Table 2 , it could be found that the simulated value of scour depth was reduced by $0.1 \mathrm{~cm}$ at the front end and $0.4 \mathrm{~cm}$ at the left and right ends. It could be seen that there was a certain error between the simulation results and the test results. This was because the simulation conditions tend to be idealized compared with the test, and there was a certain gap with the actual test environment. For example, the indoor test and numerical simulation of sediment movement were different. There was local sediment start-up in the actual test process, and some factors were ignored in the numerical simulation process. However, it was found that the regularity of the test value was consistent with the simulation value. It could be seen that compared with the unimproved device, the scour depth of the improved device had been reduced in different degrees at different measuring points. This indicated that the addition of wing plates could reduce the local scour of the device, thus extended its service life.

4.2. Parameter Analysis of Wing Plate Angle. It can be seen from the above analysis that the wing plate is a sensitive factor for the change of scour depth around the protective device. To further study the influence of the inclination angles of the wing plates on the local scour of the protective device, three angles of inclination angles of $0^{\circ}, 15^{\circ}$, and $30^{\circ}$ were given to initially judge the scour condition under different test conditions, and the results are shown in Figure 7 and Table 3 . The analysis showed that the scour depth in front of the protective device decreased as the inclination angles of the wing plates increased. At the front end measuring point, when the inclination angles of wing plates changed from $0^{\circ}$ to $30^{\circ}$, the simulated values scour depth decreased from $2.5 \mathrm{~cm}$ to $2.1 \mathrm{~cm}$, and the test values scour depth decreased from $1.8 \mathrm{~cm}$ to $1.5 \mathrm{~cm}$, and the changes of scour depth of the left and right end measuring points were similar. Among them, with the addition of a $30^{\circ}$ inclined wing plate, the depth of the scour pit was the smallest. From the above data, it can be seen that the variation trend of the simulated value was consistent with the experimental value; that is, when the inclination angles of the wing plates became larger, the local scour depth of the protective device decreased.

To further elucidate the effect of the inclination angles of the wing plates on the scour depth around the protective device, the rate of reduction of scour depth was then analyzed for both the test and simulated values. As can be seen in Figure 8, the rate of scour depth reduction increased as the inclination angles of the wing plates increased. At the left end measuring point, the maximum scours reduction rate reached $50 \%$ with the addition of the $30^{\circ}$ wing plates. It can be concluded that the change of the inclination angles of the wing angles had a great influence on the local scour depth around the protective device, and the influence on the left and right was greater than that on the front. This is because the wing plates on the surface of the protective device were symmetrically distributed along the middle vertical line, generating eddy current in the vicinity of the device, which caused the separation of the submerged flow 
TABLE 3: The results of scour depth.

\begin{tabular}{lccccccc}
\hline \multirow{2}{*}{ Test conditions } & \multirow{2}{*}{ Inclination angle $\left(^{\circ}\right)$} & \multicolumn{3}{c}{ Simulated values $(\mathrm{cm})$} & \multicolumn{3}{c}{ Test value (cm) } \\
& & Front end & Left end & Right end & Front end & Left end & Right end \\
\hline 1 & 0 & 2.5 & 2.0 & 2.0 & 1.8 & 1.8 & 1.6 \\
2 & 15 & 2.3 & 1.4 & 1.5 & 1.8 & 1.8 \\
3 & 30 & 2.1 & 1.2 & 1.4 & 1.5 & 1.7 \\
\hline
\end{tabular}

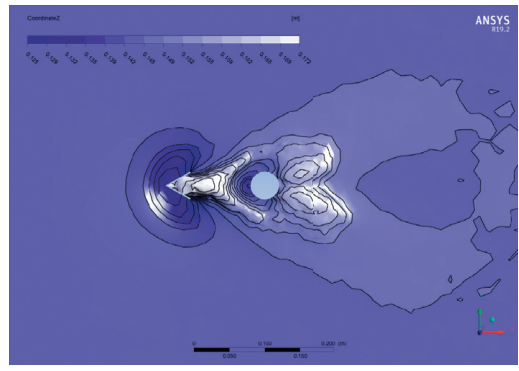

(a)

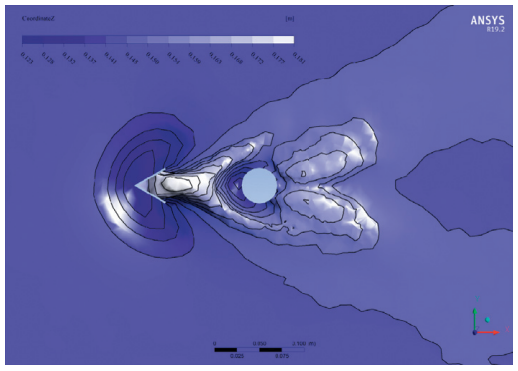

(b)

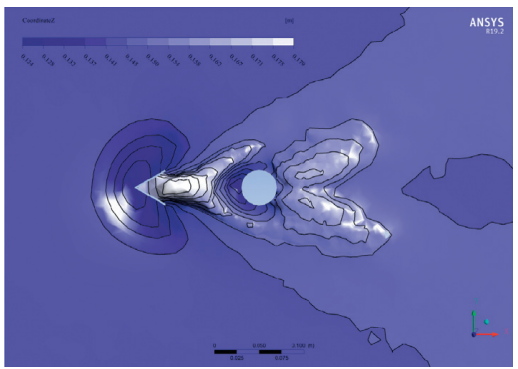

(c)

Figure 7: Contour of scour depth: (a) $0^{\circ}$ dip angle; (b) $15^{\circ}$ dip angle; (c) $30^{\circ}$ dip angle.



(a)

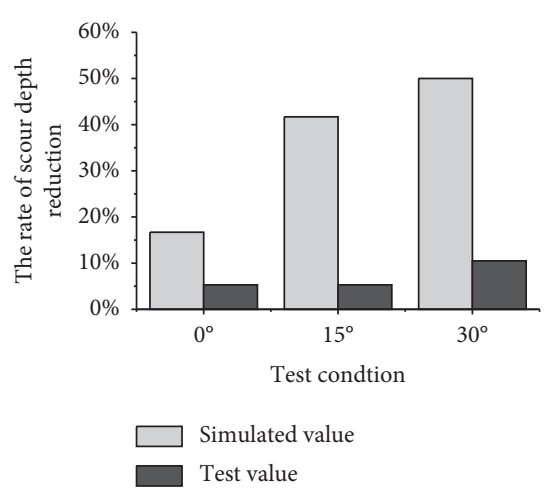

(b)

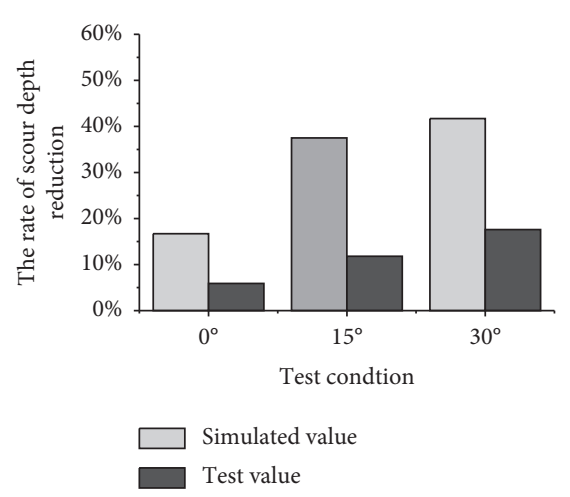

(c)

Figure 8: Change rate of scour depth of the protective device: (a) front end; (b) left end; (c) right end.

on the upstream side of the device and weaken the impact force. At the same time, there was a disturbing separation of the winding flow on both sides of the device, further weakened the eddy current system. To sum up, the impact force of the submerged flow was weakened, and the sediment carrying capacity of the eddy current system was weakened, so that the local scour of the device was effectively suppressed.

\section{Conclusions}

By comparing the indoor physical model with the numerical model, this paper analyzed the influence of the presence or absence of the wing plate and the inclination angle of the wing plate on the local scour of the protective device and drew the following conclusions:

(1) After the wing plates were installed, the local scour depth around the protective device decreased in varying degrees. With the increase in the wing inclinations, the depth of scour pit decreased. When the inclination angles of the wing plates were $30^{\circ}$, the scour reduction effect was the best, and the scour reduction rate reached $50 \%$.

(2) The three-dimensional numerical model of local scour of the protective device was established by using fluent. Comparing the simulated value with the experimental value, the variation law of the two was basically the same, which proved that fluent had high accuracy in the numerical simulation of local scour.

(3) In the test, only three measuring points for the scour depth of the protective device were arranged. In the future, the measuring points can be arranged more densely in order to better understand the change of scour depth. In addition, only three angles of wing inclinations were considered in the test, and more angles can be considered in the future experiment. 


\section{Data Availability}

The data used to support the findings of this study are available from the corresponding author upon request.

\section{Conflicts of Interest}

The authors declare that there are no conflicts of interest regarding the publication of this paper.

\section{Acknowledgments}

This research was funded by the Science and Technology Projects of Zhejiang Provincial Department of Transportation in 2019 (2019022).

\section{References}

[1] B. A. Vijayasree, T. I. Eldho, B. S. Mazumder, and B. V. S. Viswanadham, "Effectiveness of combinations of raft foundation with aprons as a protection measure against bridge pier scour," Sādhanā, vol. 43, no. 2, p. 21, 2018.

[2] N. Ali, "Control of the local scouring around the cylindrical bridge pier using armed soil by geotextile," International Journal of Geosynthetics and Ground Engineering, vol. 2, no. 1, p. 5, 2016.

[3] Q. Q. Xiang, Y. D. Li, and K. Wei, "Review of bridge foundation scouring," Journal of Southwest Jiaotong University, vol. 54, no. 2, pp. 235-248, 2019.

[4] S. J. Yang and Y. J. Liu, "Summary of new protection measures for local scour of bridge piers," Henan water conservancy and south to North Water Diversion, vol. 6, pp. 10-12, 2012.

[5] V. Garg, B. Setia, V. Singh, and A. Kumar, "Scour protection around bridge pier and two-piers-in-tandem arrangement," ISH Journal of Hydraulic Engineering, vol. 5, pp. 1-13, 2021.

[6] R. Z. Mohsen, K. Alireza, K. Hadi, and J. E. Ball, "Protecting bridge pier against local scour using flow diversion structure," Water Management, vol. 171, no. 5, pp. 1-26, 2018.

[7] R. O. Mayall, R. A. Mcadam, R. Whitehouse, and R. Burd, "Flume tank testing of offshore wind turbine structural dynamics under the influence of foundation scour and scour protection," Journal of Waterway, Port, Coastal, and Ocean Engineering, 2020.

[8] Y. Kan, Q. Wang, and G. B. Lin, "Measures to resist flood disaster of bridge gossing," Journal of Railway Engineering Society, vol. 58, no. 2, pp. 36-42, 1998.

[9] K. Wardhana and F. C. Hadipriono, "Analysis of recent bridge failures in the United States," Journal of Performance of Constructed Facilities, vol. 17, no. 3, pp. 144-150, 2003.

[10] S. Hu, Z. Wang, Y. Guo, and G. Xiao, "Life-cycle seismic fragility assessment of existing RC bridges subject to chlorideinduced corrosion in marine environment," Advances in Civil Engineering, vol. 2021, pp. 1-18, 2021.

[11] W. Wang and G. Morgenthal, "Novel crashworthy device for pier protection from barge impact," Advances in Civil Engineering, 2018.

[12] A. Tafarojnoruz, R. Gaudio, and S. Dey, "Flow-altering countermeasures against scour at bridge piers: a review," Journal of Hydraulic Research, vol. 48, no. 4, pp. 441-452, 2010.

[13] Y. M. Wei, "Study on the effect of water attack angle on the protection effect of local scouring retainer around pile group piers," Journal of Nantong Shipping vocational and technical college, vol. 16, no. 4, pp. 64-66, 2017.

[14] B. Dargahi, "Closure to " controlling mechanism of local scouring" by bov," Journal of Hydraulic Engineering, vol. 118, no. 3, pp. 504-505, 1992.

[15] Y. Chiew and M. Piers, "Scour protection at bridge piers," Journal of Hydraulic Engineering, vol. 118, no. 9, pp. 12601269, 1992.

[16] S. L. Fang, H. Chen, and X. F. Shi, "Experimental study on protection technology of local scouring and deceleration without scouring of pier with clear water," Journal of Chongqing Jianzhu University, vol. 35, no. 3, pp. 71-77, 2016.

[17] Y. S. Lan, "Study on apron protection design for Pier Scouring," Heilongjiang transportation science and technology, vol. 40, no. 5, pp. 112-113, 2017.

[18] Y. L. Zhou and H. C. Cui, "Experimental study on local scour apron protection of pier," Journal of Chang'an University (Natural Science Edition), vol. 19, no. 3, pp. 36-38, 1999.

[19] N. Ye, Experimental and Simulation Study on Anti Scour Device of Diversion Pier, Zhejiang University of technology, Zhejiang, China, 2020.

[20] H. Karami, H. Hosseinjanzadeh, K. Hosseini, and A. Ardeshir, "Scour and three-dimensional flow field measurement around short vertical-wall abutment protected by collar," KSCE JOURNAL OF CIVIL ENGINEERING, vol. 22, no. 1, pp. 141-152, 2018.

[21] V. Christopher, "Bridge pier scour under ice cover," Water, vol. 13 , no. 4 , p. 536,2021

[22] E. Akhlaghi, M. S. Babarsad, E. Derikvand, and M. Abedini, "Assessment the effects of different parameters to rate scour around single piers and pile groups: a review," Archives of Computational Methods in Engineering, vol. 27, pp. 183-197, 2019.

[23] S. O. Lee and S. H. Hong, "Reproducing field measurements using scaled-down hydraulic model studies in a laboratory," Advances in Civil Engineering, vol. 2018, pp. 1-11, 2018. 